\title{
Study on Introduction of Cashless Economy in India 2016: Benefits \& Challenge's
}

\author{
*Preeti Garg, **Manvi Panchal \\ *Research Scholar, School of Business Studies, Shobhit University, Meerut; email:preeti_garg25@yahoo.co.in \\ ** Research Scholar,School of Business Studies,Shobhit University, Meerut.
}

\begin{abstract}
This paper studied the views of people on introduction of cashless economy in India .The study was conducted in Delhi region \& data was collected with the help of structured questionnaire and analyzed using simple percentage method. Responses from respondents shows that cashless economy will help in curbing black money, counterfeit's fake currency, fighting against terrorism, reduce cash related robbery, helps in improving economic growth of our country. Major challenges that can hinder the implementation of the policy are cyber fraud, High illiteracy rate, attitude of people, lack of transparency \& efficiency in digital payment system. The study shows that the introduction of cashless economy in India can be seen as a step in right direction. It helps in growth and development of economy in India.
\end{abstract}

Keywords: cashless economy, corruption, Black money, India, Digital Payments.

\section{Introduction}

The government has implemented a major change in economic environment by demonetizing the high value currency notes of - Rs 500 and Rs 1000 from $8^{\text {th }}$ November 2016 and push India towards cashless future. What is cashless economy: A cashless economy is one in which all the transactions are done through electronic channels such as debit/credit cards, Immediate Payment Service (IMPS), National Electronic Funds Transfer (NEFT) and Real Time Gross Settlement (RTGS). The circulation of physical currency is minimum. The Indian economy continues to be driven by the use of cashless than 5\% of all payments happen electronically. Electronic based transaction seeks to drive the development and modernization of India's payment system. The essence of the policy is to shift the economy from a cash based economy to a cashless one. Efficient and modern payment system is a key enabler for driving growth and development. The policy also aims at improving the effectiveness of monetary policy, managing inflation in the economy, maintaining stable pricing system. In India, the ratio of cash to gross domestic product is $12.42 \%$ in GDP; this is one of the highest in the world. It was $9.47 \%$ in China or $4 \%$ in Brazil. Further, the number of currency notes in circulation is also far higher than in other large economies, India had 76.47 billion currency notes in circulation in 2012-13 compared with 34.5 billion in US.

The government is working at various levels to reduce the dependence on cash.PM-Narendra Modi unveiled two schemes -Lucky GrahakYojna, Digi DhanVyapaarYojna for customers and traders like to promote mobile banking and e-payments. To encourage and strengthen cashless economy it's important to inculcate the habit of making e-payments. Government encourages cashless transactions like mobile banking, Ru-pay cards, UPI, USSD these are means and methods of digital payments. Less cash economy is in the interest of everyone and it will help in creating a clearer economy in future. Government have also introduced Aadhar based payment system, this is for those people who don't have cards or mobile phones. Reducing Indian economy's dependence on cash is desirable for a variety of reasons. To control counterfeit notes that could be contributing to terrorism, It also affect the monetary policy of our country and to eliminate the "black money, hawala transfers can't be made without paper currency, Curbs illegal activities altogether. A large part of black money is generated in illegal trades like selling drugs therefore without cash or less cash illegal trade might become difficult.

RBI has also issued licenses to open new-age small finance banks and payments banks which are expected to give a push to financial inclusion and bring innovative banking solutions. Things are also falling in place in terms of technology for India. The recently launched Unified Payments Interface by National Payments Corporation of India makes digital transactions simple. Even the RBI has also recently unveiled a document, "Payments and Settlement Systems in India: Vision 2018", setting out a plan to encourage electronic payments and to enable India to move towards a cashless society or economy in the medium and long term.

\section{Benefits of Cash less Economy}

Cash less economy helps in curbing generation of black money. As a result it reduces real estate prices because most of black money is invested in Real estate which inflates the prices of Real estate markets. 1 in 7 
notes is supposed to be fake, which has a huge negative impact on economy, by going cashless, that can be avoided. An increased use of digital payment instead of cash would enable a more detailed record of all the transactions which take place in the society, allowing more transparency in business operations and money transfers which reduce tax avoidance and money laundering .Cashless Economy also reduces the cost of banking services. It also improves monetary policy in managing inflation and increases economic growth in our country. Another benefit of cashless economy is that it discourages cash related robberies and other cash-related crimes.

\section{Challenges in making India a cashless economy}

Large part of the population is still outside the scope of Net banking like use of credit or debit cards, making transactions using mobile phones, and using the internet to pay bills they are not in a position to reduce its dependence on cash. Second, about $90 \%$ of the workforce, which produces nearly half of the output in the country, works in rural sector It will not be easy for this sector to become cashless. There is a general preference for cash transactions in India. Merchants prefer not to keep records in order to avoid paying taxes and buyers find cash payments more convenient. Although cashless transactions have gone up in recent times, a meaningful transition will depend on a number of things such as awareness, technological developments and government intervention. For instance, mobile wallets have seen notable traction, and it is possible that a large number of Indians will move straight from cash to mobile wallets. The availability and quality of telecom network will play an important role. People face difficulties in making electronic payments even in metro cities because of poor network. Service providers will have to constantly invest in technology in order to improve security and ease of transaction. People will only shift when it's easier, certain and safe to make cashless transactions. The government will also need to play its part. It will have to find ways to incentivize cashless transactions and discourage cash payments.Difficulties in changing attitudes and perception of people towards moving digital payments. India is dominated by small retailers. They don't have enough resources to invest in electronic payment infrastructure.

\section{Review Of Literature}

Review of literature paves way for a clear understanding of the areas of research already undertaken and throws a light on the potential areas which are yet to be covered. Keeping this view in mind, an attempt has been made to make a brief survey of the work undertaken on the field of Cashless economy. The reviews of some of the important studies are presented below.

Cashless economy is not the complete absence of cash, it is an economic setting in which goods and services are bought and paid for through electronic media. According to Woodford (2003), Cashless economy is defined as one in which there are assumed to be no transactions frictions that can be reduced through the use of money balances, and that accordingly provide a reason for holding such balances even when they earn rate of return. In a cashless economy, how much cash in your wallet is practically irrelevant. You can pay for your purchases by any one of a plethora of credit cards or bank transfer (Roth, 2010) observed that developed countries of the world, to a large extent, are moving away from paper payment instruments toward electronic ones, especially payment cards. Some aspects of the functioning of the cashless economy are enhanced by efinance, e-money, e-brokering and e-exchanges. These all refer to how transactions and payments are effected in a cashless economy (Moses-Ashike, 2011). Marco and Bandiera (2004) argue that increased usage of cashless banking instruments strengthens monetary policy effectiveness and that the current level of e-money usage does not pose a threat to the stability of the financial system. However, it does conclude that central banks can lose control over monetary policy if the government does not run a responsible fiscal policy.

According to a 2015 report by Price Water House Coopers, India's unbanked population was at 233 million. Even for people with access to banking, the ability to use their debit or credit card is limited because there are only about 1.46 million points of sale which accept payments through cards. A study by Boston Consulting Group and Google in July noted that wallet users have already surpassed the number of mobile banking users and are three times the number of credit card users.

Objectives:Objectives of present study are as follows:

1. To study the benefits of cashless economy

2. To assess the preparedness for the implementation of the cashless economy by Indian Government.

\section{Research Methodology}

The study is conducted to obtain data on Introduction of Cashless economy in India. The study is conducted in Delhi region. A sample size of 100 was selected using the convenience sampling procedure out of which 87 copies were retrieved in usable form. This represents a response rate of $87 \%$. The sample includes both literate and illiterate population since they are the ones who give their views on introduction of cashless economy and use of digital payment methods, there response determine the reliability of survey. Survey method 
is used for collecting data with the help of questionnaire. The responses from the respondents were collected and analyzed using the simple percentage method.

\section{Data Analysis \& Interpretation:}

Table 1: Knowledge of Cashless Policy to users

\begin{tabular}{|c|c|c|c|}
\hline & & Frequency & Percent \\
\hline \multirow[t]{6}{*}{$\begin{array}{l}\text { I have heard about India's Cashless } \\
\text { Economy? }\end{array}$} & Strongly Agree & 36 & 41.4 \\
\hline & Agree & 41 & 47.4 \\
\hline & Undecided & 3 & 3.4 \\
\hline & Disagree & 6 & 6.9 \\
\hline & Strongly Disagree & 1 & 1.1 \\
\hline & Total & 87 & 100.0 \\
\hline \multirow[t]{7}{*}{$\begin{array}{l}\text { Cashless Economy should be } \\
\text { introduced in India. }\end{array}$} & Strongly Agree & 25 & 28.7 \\
\hline & Agree & 23 & 26.4 \\
\hline & Undecided & 16 & 18.4 \\
\hline & Disagree & 11 & 12.6 \\
\hline & Strongly Disagree & 9 & 10.3 \\
\hline & Missing & 3 & 3.4 \\
\hline & Total & 87 & 100.0 \\
\hline
\end{tabular}

Above Table shows that there is a high degree of awareness among the population about $88 \%$ of the respondents are aware of cashless economy in India. The study considered academic community which means, by all standards they are expected to be fairly aware of the happenings in the society. Few respondents however show a strong dislike for the cashless economy. While $55.1 \%$ of the respondents prefer that cashless economy should be introduced in India. The following reasons might have accounted for the low enthusiasm about its immediate introduction, the lack of preparedness for the system, the nation having other problems to solve now, freedom to use cash to any amount, inadequate technology, and that the flow of money will be hampered.

Table 2: Below presents the Perceived Benefits of the cashless economy.

\begin{tabular}{|c|c|c|c|}
\hline & & Frequency & Percent \\
\hline \multirow[t]{6}{*}{ It would reduce risk of fake currency } & Strongly Agree & 35 & 40.2 \\
\hline & Agree & 35 & 40.2 \\
\hline & Undecided & 9 & 10.3 \\
\hline & Disagree & 5 & 5.7 \\
\hline & Strongly Disagree & 3 & 3.4 \\
\hline & Total & 87 & 100 \\
\hline \multirow[t]{7}{*}{ It would prevent money laundering } & Strongly Agree & 20 & 23.0 \\
\hline & Agree & 28 & 32.2 \\
\hline & Undecided & 17 & 19.5 \\
\hline & Disagree & 10 & 11.5 \\
\hline & Strongly Disagree & 11 & 12.6 \\
\hline & missing & 1 & 1.1 \\
\hline & Total & 87 & 100 \\
\hline \multirow[t]{7}{*}{ It can reduce corruption } & Strongly Agree & 13 & 14.9 \\
\hline & Agree & 23 & 26.4 \\
\hline & Undecided & 19 & 21.8 \\
\hline & Disagree & 19 & 21.8 \\
\hline & Strongly Disagree & 12 & 13.8 \\
\hline & Missing & 1 & 1.1 \\
\hline & Total & 87 & 100 \\
\hline \multirow[t]{7}{*}{ It can stimulate economic growth } & Strongly Agree & 18 & 20.7 \\
\hline & Agree & 31 & 35.6 \\
\hline & Undecided & 25 & 28.7 \\
\hline & Disagree & 8 & 9.2 \\
\hline & Strongly Disagree & 3 & 3.4 \\
\hline & Missing & 2 & 2.3 \\
\hline & Total & 87 & 100 \\
\hline
\end{tabular}

Above Table shows that $80.4 \%$ of the respondents believe that the most significant benefit of the cashless economy is reducing the risk of fake currency. In the same spirit, $55.2 \%$ of the respondents believe that 
the cashless economy will help to fight against money laundering as the money flowing through the system can easily be traced. $41.3 \%$ of the respondents believe that it contribute towards reducing corruption. Another benefit is that it will stimulate economic growth as money hidden in other illegitimate areas will now be freed up. $66.3 \%$ believe that efficient and modern payment system is positively correlated with the economic development and economic growth of country.

Table 3, Below present's perceived challenge's with the cashless economy.

\begin{tabular}{|c|c|c|c|}
\hline & & Frequency & Percent \\
\hline \multirow[t]{7}{*}{ Cyber Crime } & Strongly Agree & 17 & 19.5 \\
\hline & Agree & 38 & 43.7 \\
\hline & Undecided & 18 & 20.7 \\
\hline & Disagree & 11 & 12.6 \\
\hline & Strongly Disagree & 2 & 2.3 \\
\hline & Missing & 1 & 1.1 \\
\hline & Total & 87 & 100 \\
\hline \multirow{7}{*}{ The literacy required } & Strongly Agree & 17 & 19.5 \\
\hline & Agree & 33 & 37.9 \\
\hline & Undecided & 23 & 26.4 \\
\hline & Disagree & 9 & 10.3 \\
\hline & Strongly Disagree & 3 & 3.4 \\
\hline & Missing & 2 & 2.3 \\
\hline & Total & 87 & 100 \\
\hline \multirow[t]{6}{*}{$\begin{array}{l}\text { Transparency \& Efficiency in E } \\
\text { payments }\end{array}$} & Strongly Agree & 27 & 27 \\
\hline & Agree & 26 & 26 \\
\hline & Undecided & 15 & 15 \\
\hline & Disagree & 14 & 14 \\
\hline & Strongly Disagree & 5 & 5 \\
\hline & Total & 87 & 100 \\
\hline \multirow[t]{6}{*}{ Increase in Internet fraud } & Strongly Agree & 22 & 25.3 \\
\hline & Agree & 30 & 30 \\
\hline & Undecided & 21 & 21 \\
\hline & Disagree & 10 & 10 \\
\hline & Strongly Disagree & 4 & 4 \\
\hline & Total & 87 & 100 \\
\hline
\end{tabular}

Above Table shows that there are some problems which respondents are facing to come with the cashless economy. Increase number of cybercrime, $63.2 \%$ believe that cybercrime will hinder the free implementation of cashless economy.57.4\% population are literate they easily operate digital payment system; operate mobile phones, which will ultimately increase the users of the digital payment methods. $60.9 \%$ of the respondents believe that lack of transparency \& efficiency in payment system. Internet fraud is the major problem to be tackled in the cashless economy as $59.8 \%$ of the respondents see exposure to fraudulent activities as a big problem.

\section{Findings And Policy Implication:}

From the above analysis it also appears that many people actually agree with the government on the usefulness of cashless economy as it helps to fight against terrorism, corruption, money laundering but one biggest problem in the working of cashless economy in India is cybercrime and illegal access to primary data. Therefore it's important to strengthen Internet Security from protection against online fraud. Large number of population is still below literacy rate living in rural areas .For smooth implementation of cash less system in India, the following measures are recommended Government have to bring transparency and efficiency in epayment system, strategies used by government and RBI to encourage cashless transactions by licensing payment banks, promoting mobile wallets and withdrawing service charge on cards and digital payments. A financial literacy campaign should be conducted by government time to time to make population aware of benefits of electronic payments.

\section{Reference}

[1]. Lee, Jinkook, Fahzy Abdul-Rahman, and Hyungsoo Kim. "Debit card usage: an examination of its impact on household debt." Financial Services Review.16.1 (2007): 73.

[2]. More wedge, C. K., Holtzman, L., \&Epley, N. (2007). Unfixed resources: perceived costs, consumption, and the accessible account effect. Journal of Consumer Research, 34(4), 459-467). 
[3]. Humphrey, D. B. (2004): - Replacement of cash by cards in U.S. Consumer Payments, Journal of Economics and Business, 56, 211-225.

[4]. Marco, A. \&L.Bandiera (2004): -Monetary Policy, Monetary Areas and Financial Development with Electronic Money, IMF Working Study, IMF.

[5]. Moses-Ashike, H. (2011), "Cashless Economic can Reduce Risk of Carrying Huge Cash", [Online] Available: http://www.businessdayonline.com/.../22217.

[6]. Odior, E.S., and Banuso, F.B. (2012): Cashless Banking in Nigeria: Challenges, Benefits \& Policy Implications. European Scientific Journal. Vol 8, pp. $12-16$.

[7]. Roth, B. L. (2010).“The Future of Money: The Cashless Economy - Part 1". [Online] Available: https://www.x.com/.../futuremoney-cashless-economy-part-i.

[8]. Woodford M. (2003). "Interest \& Price: Foundation of a Theory of Monetary Policy", Princeton University Press. 